Ispánovics Csapó Julianna*

Újvidéki Egyetem, BTK

Samu-Koncsos Kinga

Pécsi Tudományegyetem, BTK

Samu János

Újvidéki Egyetem, Magyar Tannyelvü

Tanítóképző Kar, Szabadka
UDC: 821.511.141.09 Nemes N. Á. DOI: $10.19090 /$ gff.2020.1.293-306

Originalni naučni rad

\title{
KÖZÖTT: A KÜLÖNBSÉG KRÍZISE ÉS VÁGYA NEMES NAGY ÁGNES KÖLTÉSZETÉBEN
}

Nemes Nagy Ágnes a 20. század második felének kiemelkedő magyar költője. Költészete a század történelmi kataklizmáiról tesz tanúságot, annak a társadalmi/erkölcsi/nyelvi rendnek a válságáról, amit Jacques Lacan pszichoanalitikus szubjektumelmélete Szimbolikusnak nevez. A tanulmány Nemes Nagy lírájának emblematikus darabját, a Közöttet elemzi. Megközelítése szerint a vers alakzatai a jelentés költői elbizonytalanítása-kijátszása révén a jelentés traumatikus összeomlásáig vezetnek, azaz a jelölő és a jelölt, az én és a másik, a test és a nyelv közti határ sérüléseit viszik színre. Ezt a köztesség-tapasztalatot Julia Kristeva az abjekt teorémájával ragadja meg. Az abjekt az a határsértő nem-tárgy, amely veszélybe sodorja a szubjektum integritását, mert odavezeti a szubjektumot, ahol szubjektum még/már nincs - hiszen az említett határ/különbség a jelentés és bármiféle identitás alapja, lehetőségi feltétele. Nemes Nagy Ágnes érett költészete éppen ezért nem valamiféle jelentésre, sokkal inkább a jelentés (illetve az identifikáció) feltételére irányul, egyszerre hangot adva a különbség krízisének és vágyának. A dolgozat teoretikus alapját Julia Kristeva, Jacques Derrida, Georges Didi-Huberman és Kiss Attila Attila szubjektum- és művészetfilozófiai munkái adják, melyek felöl az elemzés gondolatmenete a Nemes Nagy-líra befogadástörténetének kurrens meglátásaihoz is kapcsolódik.

Kulcsszavak: Nemes Nagy Ágnes, a jelentés válsága, tanúságtétel, trauma, befogadástörténet.

*csapo@eunet.rs 
„Az esztétikai - és különösen az irodalmi - alkotás, valamint a vallási szöveg képi fikcionális mivoltában olyan konfigurációt ad, amelyben a prozódikus ökonómia, a jellemek és az implicit szimbolika különösen hüséges megjelenítései a szubjektum összeomlással folytatott harcának.” (Julia Kristeva: A melankolikus képzelet)

Nemes Nagy Ágnes kései lírájának jellemző gesztusa - klasszikus szöveghelyeinek az ön-újra-megtalálás lehetetlenségét ily módon is színre vivő rekontextualizálása, dekonstruálása, újrahasznosítása mellett - a tárgyias működésmód tematizálásának felerősítése. A korábban elemzett (Samu-Koncsos, 2017) Az utca arányaiban a tárgyias mögétekintés már nem talál nyugvópontot, csak helyettesek végtelen láncolatát, jelölt helyett további jelölöket - mintha e müködésmód nem is a megfelelő jelölő megtalálására törne, hanem annak megtalálása utáni feláldozására a jelölőhálóból hiányzó, és épp ezzel a jelháló működését katalizáló, a jelölést mint olyat egyáltalán életre hívó negativitás, hiány, tiszta különbség (közöttség) oltárán, amely szakadéknak Nemes Nagy Ágnes költészetében a levegő a metaforája.

E tanúságtevő, posztapokaliptikus lírában minél pontosabb a jelölö, élesebb a kép, annál biztosabban éri el célját: elégtelenségét, „még-ez-sem-az”-ként való lebukását - „párolgásában” (Eső, hó), fakulásában, „foszlásában” (Között, Négy kocka) a levegő egyre halkuló dicsérete hangzik el. Ez a költészet nem a láthatót magasztalja, hanem a mögötte feszülő hátteret, amely fenntartja azt, miközben hiányzik belőle: egyrészt a levegőt mint létszükségletet (,a lét lélegzetét” Teraszos tájkép); másrészt a tüdőből a hangszálak felé áramló levegőt mint a megszólalás feltételét, a hangot adó némaságot (Lement a nap); harmadrészt a vásznat, aminek helyét a müvészi tárgy elfoglalja / a primer nárcizmus szakadékát, amely fölött az identitás feldereng (tematikusan többek között a Négy kocka utolsó versszakának bekeretezett-mediált égdarabja, a Szél előtérbe szökő hátterének aspektusváltása, a Múzeumi séta nézö és látvány, alak és háttér megkülönböztethetőségét, illetve bármilyen metapozíciót kiiktató levegö-oszlopai, szerkezeti szempontból pedig általában a kései prózaversek „monolitikus” logikája); negyedrészt a szövet/szöveg szemeit, pórusait vagy negatívját (Jegyzetek a félelemröl, Között), ami a jelölöháló különbség-logikájának alapja. Ilyen szempontból az önleleplező Nemes Nagy-tárgyiasság áldozati: „szavainak fonadékát" (A fémben én vagyok a láthatatlan) a levegőnek mint 
tárgyiasíthatatlannak ${ }^{1}$, a tárgyiasítást lehetővé tevő, de abból magát minduntalan kivonó lehetőségi feltételnek ajánlja fel, nagyon feltünő birtokos szerkezettel költészetének egyik csúcspontján: ,a levegő nagy ruhaujjai” (Között).

„A levegő nagy ruhaujjai” Nemes Nagy Ágnes egyik legösszetettebb képe; a költészetében többször előforduló (a Vihar például teljes egészében erre épít) száradni kiakasztott tiszta ruha katartikus látványából indít, s Nemes Nagy jellegzetes aspektusváltásával az alakról a háttérre irányítja a figyelmet, a textilszálak (textus) mögöttesére, mintegy negatívjára: a mögékerültség átlátszó leplére, a szubjektum saját majdnem-semmijére, amely a Nemes Nagy Ágnes-féle karokkal, ujjakkal összhangban egy elérhetetlen valami (illetve majdnem-valami) felé való nyújtózás pillanatának végtelen magányában ,jelentésükig el nem érve” (Ekhnáton az égben) sodródik. Egyszerre kötődve testhez (biológiai értelemben vett szövethez, a különbséget nem ismerö érintéshez) és textushoz (a szövethez mint jelhálóhoz, a különbségek játékteréhez), nem-hely: Un-Heim: a test távolsága, a jelölt (abjekt) hiánya, a képzelet utópiája, az, ami át-tetszik, üres ígéret vagy az üresség ígérete.

Az első versszak ennek a negatív lepelnek, átlátszó takarónak a kifejtése. „A levegő, amelyen szilárdan / támaszkodik madár s madártan”: a légellenálás fizikai törvényét retorizálja a paradox kép: megszilárdítja a légnemüt; a repülés materiális feltételeként a levegő láthatóvá válik, a madár megtestesíti és megmutatja a láthatatlant - a támasznak és ellenállásnak éppen olyan kölcsönviszonyában, amely a (költöi) jelentést az elveszett tárgyhoz ${ }^{2}$ füzi a különbség elválasztó kötelékeivel. A levegő nemcsak a madártestet tartja fenn, de a madárral-angyallal eljegyzett szövetet is ${ }^{3}$ : a „madártan” imaginárius tudástérképünk szinekdochéja, otthonos értelemszövedék (fenotextus), identifikációs csomópontok hálózata, amelyet az alapjául szolgáló levegő sodor (veszélybe), rojtoz ki - a jelháló zavarának vagy krízisének (fantázia/költészet és trauma különbsége csupán

\footnotetext{
${ }^{1}$ Olyasminek, ami csak a szubjektum eltünésében, a kereső elveszésében mutatkozik. Nem véletlen, hogy a Teraszos tájképben a szél „,a lét lélegzete”, a lét ugyanis (ellentétben a létezővel) nem tárgy, nem is képződhet vele szemben szubjektumpozíció. Noha a Között kezdősorának szerkezetében (,a levegő nagy ruhaujjai”) a levegő nem birtok, hanem birtokos, „a lét lélegzeté”-hez hasonlóan a Között-beli szövet is a szubjektum eltünésének/megjelenésének billenékeny pillanatára veti ki hálóját.

${ }^{2}$ A lacani objet a-hoz.

3 A ,madár és madártan” és kötőszava így tulajdonképpen egy hasonlatot takar, az ellenállásnak-támasznak strukturális azonosságát feltételezi a madár és a levegő, illetve a tudás és az azt megképző és fenyegető új, hiba, kivétel, deviáns érzet ürje között.
} 
fokozati), az identitás extázisának, a mögétekintésnek fenyegető gyönyörében: „az érvek foszló szélein a szárny”4. Ilyen szempontból „A levegő nagy ruhaujjai” radikálisan billenékeny, aspektusváltó kép: jelenti egyrészt a fent jellemzett mögöttest, hátteret, ürességet, másrészt az afölött feszülő nárcisztikus vetítővásznat/védőköpenyt (vö.: Eső, hó...), amelyen a jelentés mintázatai felderenghetnek - voltaképpen a kettő elválaszthatatlanságára, „szolidaritásukra” mutat rá:

„a nyelv és annak elsajátításáról szóló elméletek mélyében a szimbolikus funkció kiindulópontját konstituáló üresség az, ami úgy mutatkozik, mint az első elkülönítés aközött, ami még nem Én, és aközött, ami még nem tárgy. (...) A nárcizmus védi az ürességet, létezővé teszi azt, és így, mint ezen üresség ellentéte, alapvető elkülönülést biztosít. A nárcizmus és az üresség közötti eme szolidaritás nélkül a káosz magával vinné a különbségtevés, a nyom és a szimbolizáció minden lehetőségét, és összezavarná a test, a szavak, a valós és a szimbolikus határait" (Kristeva, 2007: 7).

A kezdőkép száradó ruhái az ént létrehívó nem-én, szinte-én, én-feltétel megtisztítására (abjekcióra) ${ }^{5}$ irányuló vágyat hordoznak, amelyet a következő sorok írnak körül: „egy percnyi ég beláthatatlan / következményü lombjai, / az élő pára fái, felkanyarodva / akár a vágy, a fenti lombba, / percenként hússzor lélegezni / a zúzmarás, nagy nagyalokat." A fa/lomb jelentésmezejét Nemes Nagy Ágnes költészetében rendszerint a megváltás, megtisztulás, ön-újra-megtalálás (hírhozófunkció, s mint ilyen, költői beszéd) képzetei alkotják, itt mindez a felhővel mint az ég fátylával, az égen megjelenő mögöttest ígérő jelsorral, mindemellett a változás, a metamorfózis hagyományos szimbólumával eljegyzett; végső soron „a levegő nagy ruhaujjai”-nak másik neve lehet az „,egy percnyi ég beláthatatlan következményü

${ }^{4} \mathrm{Ne}$ tekintsünk el a szél légmozgás-értelmétől, ami éppen azt a folyamatot (signifiance) lopja be a jelentésbe, amely az értelmes nyelv határainál (széleinél) kísért.

${ }^{5}$ A Helikon Kiss Attila Atilla által szerkesztett Posztszemiotika-számának fogalomgyüjteményében szereplő definíció szerint ,az abjekció mozgás. Vonzás és taszítás feszültségéből töltekező mozgás, amelynek mélyéről egy sem nem szubjektum, sem nem objektum, valami türhetetlen egyszerre rémiszt és hívogat. Ez a szubjektum számára felfoghatatlan, radikális kívüllét magát a szubjektumot is önmagán kívülre löki, ún. nárcisztikus krízist provokál. Ekkor az én és a másik, a kint és a bent megkülönböztethetetlenül összevegyül, konfrontálva bennünket az elsődleges elfojtás határával, ahol és amikor az anyai testtől való elszakadás, vagyis a létezés feltétele, még nem jött létre. Az abjekció a szent megtapasztalása, s mint ilyen, alapvetően kapcsolódik a szenny és a mocsok tabujához." (Kiss, 1995: 155) 
lombjai” - a lebomló és újrasodródó jelentésháló rögzíthetetlen értelmei az „élő pára fái"-nak, a lélegzésnek (léleknek, identitásnak) oda-visszahullámzó mozgásával korrelálnak. Hogy ez a vágy megtisztulási vágy, nemcsak a száradni kiakasztott ruha asszociációi sejtetik, hanem az is, hogy a Nemes Nagy-féle megváltó fához kapcsolódik (vö. Lélegzet). Fontos azonban, hogy nem szóra, beszédre irányul, hanem lélegzésre; nem kimondásra, hanem a kimondás feltételére; nem valamiféle értelemre, hanem az értelem megszületésének lehetőségére; nem azonosságra, hanem elkülönböződésre - nincs rögzített kimenetele a metamorfózisnak, nem rajzolódik ki identitás, önkívületben/-tagadásban marad, egy abjekció-folyamat megtisztulási erőfeszítésében.

$\mathrm{Az}$ ideiglenesen feltáruló égdarab kísérteties, kizökkentő, szédítő tapasztalata (,egy percnyi ég beláthatatlan következményü lombjai”) megosztja a „percenként hússzor lélegezni a zúzmarás, nagy angyalokat” vágyát. A percenként hússzori légzés nem nyugalmi légzés, utalhat ez a légzésszámot megemelő magaslati levegö ritkaságára, gyönyörü rejtett metaforával ${ }^{6}$ szemléltetve a mögétekintés emelkedett élményét, az egyre lihábbá váló ismeretháló táguló szemeinek mögöttes-ígéretét, amely a transzcendenciával való találkozás „visszaájító" abjekt-élményével kecsegtet/fenyeget ${ }^{7}$. A Között angyalainak iszonyatos aspektusát a „zúzmarás” jelzőben megbúvó „zúz”, „mar” igék agresszivitása, valamint Dante bukott angyalának felrémlése hordozhatja, ${ }^{8}$ a „nagy”

${ }^{6} \mathrm{E}$ rejtett metafora újra természettudományos ismeretet retorizál, illetve annak eleve retorikus aspektusát vonja elötérbe. Az első versszak tehát módszeresen a rendháló zavarára/krízisére irányítja a figyelmet, a tárgyiasíthatatlan háttér extatikus előtérbe kerülésének mozzanatait írja körül, melynek során mind a látvány (repülő madár), mind a nézö (megemelkedett légzésszám) elfe(le)dett alapjai feltárulnak, ezzel kettejük különbsége is elmosódik. Mint ahogy a levegő a látványban, a légzés is háttérben marad zavartalan testi működés esetén, önkéntelen, nem követel figyelmet. A deviáns légzés az automatikus értelmeket megzavaró vagy megdöntő fenyegetés testi, materiális vonatkozását húzza alá. A látvány és a néző materialitása átüti, akadályozza a jelentéstulajdonítás automatikus (imaginárius) működését.

${ }^{7}$ A Téli angyal-béli Mária-alakéhoz hasonló tapasztalattal, amelynek vadmadárszerü, rilkei „iszonyú angyalát” a szél átlátszó szövete borítja: „Jött az ajtón ablakon / Jött fedélen és falon / Mész között kő között / Négy égtájról körbefújó / Szélsuhogásba öltözött”.

${ }^{8}$ Dante Lucifere jéggé dermeszti a pokolmélyi tájat („Oly helyen jártam - versbe venni félek -, / hol átlátszón mint szálka az üvegben, / egészen jég alatt volt minden lélek;”). A Dantekapcsolatot szempontunkból leginkább az indokolja, hogy a bukott angyalt mint a rend fenyegető kivetettjét, számüzöttjét az abjekt mitologikus megjelenítőjeként értelmezzük 
megismétlése pedig a ruhaujjakhoz csatol vissza: a Között felemelö-iszonyatos nagy angyalai a levegő nagy ruhaujjainak adnak újabb nevet, egy tárgy nélküli (és meglehet: tárgytalan) ígéretnek, amire a megtisztulási vágy, a különbség megtisztításának, a szubjektum szövet-szemekben, a megsürüsödő jelentés öneltörlésében bekerített semmijének, majdnem-valamijének, a tiszta átlátszóság szépségének vágya irányul.

Az első szakasz másik darabja, a vers második versszaka az első negatív tükre: noha az „egy percnyi figyelem-lazulás” a korábbiak széthulló lepleire rezonál, ${ }^{9}$ itt alapvetően ellentétes müködésről: koncentrációról (sűrítésről és összpontosításról) van szó:

„És lent a súly. A síkon röghegyek / nagy, mozdulatlan zökkenései, / amint feküsznek, térdenállnak / az ormok és a sziklahátak, / a földtan szobrai, / a völgy egy percnyi figyelem-lazulás, / aztán megint a tömbök és a formák, / meszes csonttól körvonalig / kővé gyürődött azonosság” (Nemes Nagy 2003: 79).

A figyelem egy előzetesen adott sík - az első versszak metaforájával: vászon (jelháló) mint projekciós felszín - módosulásaiban nyilvánul meg, hangsúlyozva, hogy az alak és a háttér nem különül el egymástól, az alak a háttér kitüremkedése inkább: a sorhatár azt a benyomást kelti, mintha a sík és röghegy között felület-figura-viszony lenne, de a soráthajlást követve világos, hogy a röghegy a felület zökkenéseként, redőjeként, gyürődéseként jön létre. A „mozdulatlan zökkenései”, illetve „a földtan szobrai” paradoxon-pár a földtan bizonytalanságát emeli ki: a nagy, mozdulatlan zökkenések léptéke beláthatatlan a számára (használjuk az első szakasz kifejezését most egy másik értelemben), hozzáférhetetlen, továbbá imaginárius tudás-konstrukcióit alakzatokban építi ki,

(Kristeva az abjektet „bukott tárgy”-ként írja le; lásd Kristeva, 1982) S mivel az abjekció mindig egyben saját létünk abjekciója, ájulás (lásd erről bővebben Gyimesi, 1995), nem véletlen, hogy az Isteni szinjáték túlvilági utazója Dis köztes nem-helyén, a bukott angyal szőrén szédülten lefelé/felfelé kapaszkodva, a Nemes Nagy-féle „Tán így a forditott?” (A kín formái) abjekt-tapasztalatában elveszíti irányok és jelölök különbségeit: „Hogy lettem ekkor megdermedve szótlan, / megírnom olvasó hiába kéred, / mert kevés lenne azt megírni szóban. / Még nem halál, s már nem volt bennem élet; / értse, kiben van képzelet csirája, / hogy lelkem élet s halál közt mivé lett.” Illetve: „A jég hová lett? S hogy fordult igy ez fel / lábbal az égnek? s a nap merre hágott, / hogy ily hamar hajnal cserélt az esttel?" (Az Isteni szinjáték részleteit Babits Mihály fordításában idézem.)

9 A szóismétlés szintjén is: „egy percnyi ég beláthatatlan / következményü lombjai”, „percenként hússzor lélegezni / a zúzmarás, nagy angyalokat”. 
mint a müvészet. A tudás - a ,földtan” rímel a korábbi ,madártan”-ra, melynek kapcsán az érvek provizorikussága került előtérbe -, illetve a müvészi tárgy „,szobor” - alapja, Helye ez a sík, amiből a forma, a (müvészi) jelentés mindig-már kigyürődött vagy kihajtódott a létbe. A figyelem meggyürődése, a jelek összerándulása, az identifikáció kontúrozó agresszivitása, amely a rögből szobrot, a tömbből formát, a meszes csontnak körvonalat vés, meghatározott egységgé avatja a tagolatlan testet, kontextusba köti a deviáns érzetet, pontosan az előző versszakban tematizált extázis ellentéte. Az első versszak szövet-metaforikájához a „kővé gyürődött azonosság” kapcsol vissza. Míg ott a háló majdnem széthullik, túl liha, a második versszakban mintha túlságosan sürüvé válna, majd összehajtogatódna a jelölők érintkezéséig, megkülönböztethetetlenségéig, az utolsó sorra a sík vászon áteresztőképességét vesztett, önmagába burkolózó, sokrétegnyi gyürődéscsomó, olvashatatlan palimpszeszt, köldök: egyik sem szolgálhat vetítővászonként egy születő identitás számára, amely a széthullás és a tömörödés szélsőségei között, ,az ég s a föld között” derenghetne föl. Az első szakaszt lezáró sor tehát a szétfoszlás és a kővé gyürődés közti ép felületetre, az ürességet védő nárcisztikus vetítővászonra, az identitás tabula rasajára irányuló vágyat mondja ki és hallgatja el, amelynek a nyelvtani hiányosságból fakadó jelentés-vákuum a szinekdochéja.

A második szakaszban a „kővé gyürődött azonosság” a támadási vagy erővonalak metszéspontjába kerül:

„A sziklák roppanásai. / Amint a nap átlátszó ércei / már-már magukba, fémmé a követ, / ha állat járja, körme füstölög, / s köröznek fent a sziklafal fölött / az égő paták füstszalagjai, / aztán az éj a sivatagban, / az éj, amint kioltja s kőmivolta / magváig ér, fagypont alatti éj” (Nemes Nagy 2003: 79-80).

A kezdősor hangutánzó szava jellemző: a nyelv hangzósságának előtérbe állítása a jelölőt észrevétlen fenntartó materiális alap felé mutat, s ez - a szövet színeváltozása textusból sejtszövetté - a későbbi szöveghelyeken egyre hangsúlyosabbá válik. A kő-azonosságot (identitást) kezdetben a tüző nap ,átlátszó érceinek" bekebelező, magába olvasztó aktusa veszélyezteti. Mindenképpen föltünő, hogy a nap megmutatását, a fény megtestesítését (ami az első versszakbéli levegö-megszilárdítással analóg) az érc-metaforára bízza a szöveg. A kőzettani kifejezéssel a napfényt a kőhöz teszi hasonlatossá, miközben a napfénynek éppen arra az agresszív, inkorporáló gesztusára utal, amelyben az magába olvasztja, magához hasonlatossá, magáévá teszi a követ. A metafora ez esetben is természettudományos ismereten épül ki; a fémet kőből olvasztják, amely fém itt magába olvasztaná a követ. Ez az egymástükrözés olyan végtelenített 
aspektusváltás, amelyben az azonosulás lehetetlen, csak „már-már”, szinte valósulhat meg, ugyanakkor a fentiek értelmében a különbségtevés is kizárt. Akárcsak a gyürődés maga-takarása esetében, a külső és belső közti különbség elötti vagy utáni, kiazmikus szerkezethez érünk, azonosság és különbség között, éppen az abjekt-szakaszban találjuk a szöveg implicit szubjektumát. „A nap átlátszó ércei” ennek megfelelően olyan hiányzó (átlátszó) tekintet, amely integrálja a követ a láthatóság birodalmába, s így a tárgy nélküli azonosulást, az én nem-énként való világrajöttét indikáló Imaginárius Apa alakzataként is fölfogható, amely megvilágítva láthatatlanná tesz, hiányként, elveszésként jegyez be a jelölők közé.

„Jegyezzük meg rögtön, hogy az így felállított legarchaikusabb egység az Anya által vágyott Fallosz, amely annyira autonóm identitás, hogy eltolódásokat teremt: ez az imaginárius Apa egysége, az Anya és az ő Vágya összeolvadása. Az Imaginárius Apa lenne a jele annak, hogy az Anya nem Teljes, hanem akar... kit? mit? A kérdésre nem létezik más válasz, mint az, amely feltárja a nárcisztikus ürességet: 'Mindenesetre nem én.' Nem lehetséges-e az, hogy Freud híres kérdése, 'mit akar a nő?, egy még alapvetőbb kérdés visszhangja:'Mit akar az anya? Ugyanabba a lehetetlenbe ütközik bele, mint amit egyfelől az Imaginárius Apa, másfelől a nem én' szegélyez. És ez a nem én az (lásd Samuel Beckett darabja ugyanezzel a címmel - Not I), amelyböl az Én fájdalmasan elő akar törni” (Kristeva, 2007: 12).

Kiazmikus erők formálják meg a között-lét szubjektumának folyamatos metamorfózisát, szinte-létét: míg a fény elnyel, integrál, résszé, belsővé tesz, eltakar, miközben átlátszó, addig az éj széthasít, dezintegrál, részekre bont, a belsőt külsővé teszi, feltár, miközben vaksötét. A nap - noha megvilágít - elfed, eltünésként mutat meg, az éj pedig felfed - noha láthatatlanként, nemlétként: a szubjektum - a másik hiányával azonosulva, illetve önmagától elkülönböződve mindig már/még szinte-láthatatlan vagy szinte-látható. A Között szubjektuma két nemlét, egy már-nem-én és egy még-nem-én folyamatos aspektusváltásában tünik (f)el: „,s amint hasadnak és szakadnak / a porcok, forgók, kőlapok, / amint feszítik véghetetlen, / széthasgató önkívületben / a fehér s a fekete mindennapos / néma villámcsapásai - // A nap s az éj között." A szövet-metaforasor további réteggel gyarapszik, hiszen a hasadás és a szakadás (mint a belső külsévé válása, illetve a háttér előtérbe kerülése - amely jelentéseket a fenti konzekvenciákkal járó hangutánzó szavak hordozzák) a végtelen feszítéssel egészül ki: a vászonnak feszesnek kell lennie, hogy az általa hordozott kép ne torzuljon; a széthasgató önkívület azonban, ami a fekete-fehér különbségéből, a nem-én két fentebb meghatározott, naphoz és éjhez kötődő hiányából fakad, még/már nem teszi lehetővé, hogy az identitás kontúrjai kirajzolódjanak ,a nap s az éj között”. Nemes 
Nagy azonban némán itt is felnéz: a „hasadás” nyelvi asszociációja ugyanis nem az alkonyathoz, hanem a hajnal reményéhez kötődik, ezért egy „várakozási horizont nélküli várakozás" ${ }^{10}$ tapintható itt ki, az identitás hajnalhasadásának fohásza.

Ez a fohász nyilvánul meg a Között-háló két feltűnő, egymástükröző csomópontjában, az első versszakbéli „az élő pára fái” és a jelen szakaszban szereplő „az égő paták füstszalagjai” szöveghelyeken. Míg az élő pára fái egy értelmet megelőző üresség megtiszításának vágyát fejezik ki, addig az égő paták füstszalagjai egy transzgresszív érintés, egy sérülés jeleként értelmezhetők, amely ráadásul maga is a sziklafal fölött, vagyis egyfajta határátlépésben mutatja magát. Az égő pata, füstölgő köröm persze az ujjakkal (a levegő nagy ruhaujjai - a ruha, a szövet jelentésmezejébe pedig a szalag szövi bele a szöveghelyet), illetve a szárnnyal (az érvek foszló szélein a szárny) is rezonál, így az angyalhoz (lásd még égő) is kötődik - a traumához és az imához egyaránt (az imához azért, mert az előző szakaszban még térdenálló - erősen megszemélyesített - sziklahátak felett kering, másrészt pedig, mint ahogyan Z. Urbán Péter Között-elemzésében (Urbán, Z. 2015) rámutat, maga is az égőáldozat képzetkörét mozgósítja), ezzel egyszerre megelőzve és követve az első szakasz képét - a posztapokaliptikus időtapasztalat ellehetetleníti a szöveg lineáris olvashatóságát.

„Az idő pszichikai háló. A szálak metszéspontjában egy csomó van, egyfajta csillag. (...) A reminiszcenciákkal teli jelen feltételezi, hogy 'kiismerjünk' - minden irányban bejárjunk - egy csillagrepedésekkel teli pszichikai hálózatot. Ez épp az ellenkezője annak, mint mikor visszaidézünk egy gyermekkori emléket, a 'pszichoanalitikus gyakorlat' módján, amely tisztázza, hogy mi volt először, utána és legvégül. A pszichikai idő anakronizmusában nincs se először, se utána, se legvégül. Nem egészen olyan, mint egy történet. Nem elbeszél, hanem intenzitástömbök, emlékezetes helyek, erőcsomópontok által tapasztalható meg" (Didi-Huberman, 2013: 19).

(Ha már felmerült a gyermekkor, jegyezzük meg zárójelben, hiszen jellemző, hogy Nemes Nagy Gyermekkorom című versében „első holt korom”-ként említi a születését megelőző időszakot, amellyel - szemben a gyermekkori emlékek

${ }^{10}$ „Az első név: a messiási vagy messianizmus nélküli messianikusság. Ez lenne az eljövő jövőre való megnyilás, vagy a másiknak - mint az igazságosság elérkezésének - a jövetelére való megnyilás, de várakozási horizont és profétikus elökép nélkül. A másik jövetele csak ott jelenik meg egyedi eseményként, ahol egyetlen elövételezés, elörejelzés sem látja jönni, ott, ahol a másik és a halál, amiként a gyökeres rossz is, bármelyik pillanatban meglepetésként felbukkanhat." (Derrida, 2006: 32.) 
„rosszízü, sosem szeretett táj”-ával - azonosulni tud: az élet így nemcsak két halál „résnyi szünetében” (De nézni) tünik fel, a posztapokaliptikus tapasztalat allegóriájaként, de az elveszett tárgyra irányuló melankolikus képzelet müködése is kitapintható: a zsebben lapuló gally, amellyel írni lehet, rejtett az egyetem nagy kéményének fallikus Tekintete elöl, egy tolvaj, deviáns, vagyis költői nyelvet hordoz, amelynek témája, tétje az ön-újra-megtalálás déja-vu-tapasztalata, egy szeparáció és nyelv előtti abjekt-állapot, amit a nyelv megtagad, s ami felé törekszik.) ${ }^{11}$ A Között szövetén a posztapokaliptikus idő „,pszichikai hálója” vet ráncot: az egymást értelmező és egymás jelentéslehetőségeit kioltó csomópontok sorozata a jelentéstöbbleteket jelentéshiányokként leplezik le, az egymásra rárakódó, a jelentést az olvashatatlanságig sürítő rétegek, vagy épp az értelmezői paranoia foltozó mechanizmusának kitett értelemvákuumok alineáris, vonzó, szétszálazandó és befoltozandó szövevényében folyton el- és elmosódik a víztükrön túlról visszanéző nárcisz-arc.

A harmadik szakasz kényszeresen megismétli a hiánytapasztalat jelölöit (,szaggatások, hasgatások”), s a szemiotikus zajlás felerősödésével (ahogy a hangutánzó szavak a jelentésalkotást megzavaró materialitást engedik előtérbe) dadogásba (víziók-vízhiányok, között-kő, tan-tank ${ }^{12}$ ) fordul, „tagolatlanná” válik az

${ }^{11}$ Hernádi Mária Nemes Nagy Ágnes költészetét a tájvers alakulásának tükrében vizsgálva olyan vágyott tájat sejt meg a Nemes Nagy-líra hátterében, ,amely költészetében mint az eredet, a sértetlen egész helyszíne jelenik meg. Olyan kezdet színtere ez, amely egyszersmind végcél, beteljesülés is - és olyan végcél helyszíne, ahová a vers beszélője úgy vágyakozik, mintha már tudása, tapasztalata lenne róla." (Hernádi, 2012) Az ön-újramegtalálás dinamikáját érhetjük tetten Hernádi Mária meglátásában, nézöpontunkból azonban a „sértetlen egész"-et a szubjektum hiányként való megjelenését megelöző ősegységként (abjektként) értelmezzük, amelyhez a szubjektum jelölö-létét, illetve identifikációs folyamatait fenntartó vágy kötődik, ugyanakkor amelynek a szimbolikusba való betörése lerántja az illuzórikus én-konstrukciót - a csábító/fenyegető ön-újramegtalálás a nyelv rendjén belül lehetetlen. Hernádi Mária a Között (általában a Napfordulókötet tájai) kapcsán „megtalált” tájról ír, olvasatunkban azonban ,a megtalált egység” nem a megtisztulás, feltámadás (költői identifikáció) helye, hanem nagyon hangsúlyosan a különbségek közti határvonalak traumatikus elmosódásáé, ahol a szubjektum elveszésként találja meg magát, már-nincs és (a megtisztulás vágyának Nemes Nagy Ágnesre jellemző abjekció-aspektusváltásával) még-nincs.

${ }^{12}$ A „tan” itt nem, de korábban többször is szerepelt, kimondva (,madártan”, „földtan”) és kimondatlanul (a természettudományos ismeretekre építő alakzatok révén), egy szabályos gondolatritmus ide pozicionálná ismételt megjelenését, a dadogás ritmuszavara azonban a 
értelmes beszéd: „A szaggatások, hasgatások, / a víziók, a vízhiányok, / a tagolatlan feltámadások, / a függőlegesek türhetetlen / feszültségei fent és lent között - // Éghajlatok. Feltételek. / Között. Kö. Tanknyomok.” Szavak teste, hasonló hangzása áttevődéseket hoz létre a jelentések között, ráhajtódásokat, amint a textus működése egyre hasonlóbbá válik az élő szövetek zajlásához (Nemes Nagy Ágnes kifejezése, „az élők mértana” ilyen szempontból is átgondolható): megbomlások, érintkezések és megsürüsödések (vízhiány(i)ók), a szóképek ősi mozdulatai mentén, egy - Kiss Attila Atilla szenzációs fogalmával - betürésben ${ }^{13}$ (Kiss, 1999), hogy felderengjen egy sivatagban szomjazó, hallucináló vándor, talán istenlátta próféta képe, akire majd a „két sötét tábla” is utal. A tagolatlan feltámadás egy abjekt-szakaszba való visszaájítás, feltámadás, de nem valami meghatározottként, hanem másként, idegenként, nem-énként (a tükör-stádium víziója fog majd tagolni, de ez egy azt megelőző tapasztalat - a vízhiány tükröződő felület hiányaként is értelmes). A beszédre is mondjuk, hogy tagolatlan, artikulálatlan, értelmetlen, a jelentéskülönbségeket összezavaró, egybefolyó, ami a kimondás szubjektuma szempontjából az „így a forditott?” különbségeket elsodró, „(be)türhetetlen” krízistapasztalatát fogalmazza meg önmaga folyamatos eltörlésében, világmegragadó rendháló-jelölőinek visszavonásában, a túl nagy szeművé foszlott vagy ronggyá gyürt merítőháló lezárulhatatlan kivetésében.

Ezen a ponton érkezünk el Nemes Nagy különös hírmondójának, a szabálytalan ismétlésekben a „szent Ritmusnak”, „Isten versének ritmusának” válságát és vágyát dadogó, posztapokaliptikus-derridai prófétájának oázislátomásához: „Egy sáv fekete nád a puszta-szélen, / két sorba írva, tóban, égen, / két sötét tábla jelrendszerei, / csillagok ékezetei - // Az ég s az ég között." A nád mérték (kánon), törvény, értelem, írás, de ezt az írást a semmi (pusztaság, sivatag) szegélyezi, járja át, majdnem-némaság, dadogás: az első versszakbéli „az érvek foszló szélein a szárny” tükörképe, amire a megismételt „szél” szó is rámutat. Miként a nád, a toll (szárny) is íróeszköz; eszerint a jelenlegi nádsor azért is lehet „két sorba írva”, mert az első szakasz egén már megjelent, ezt tükrözi a zárószakasz nádsora (vagy fordítva) - végül tükröző és tükrözött, a jelentéstöbblet (költői nyelv) és a jelentéshiány (dadogás) folyamatos aspektusváltását, egymástükrözését a

\footnotetext{
„tanknyomok” traumatikus képévé torzítja a rendhez, értelemhez, identitáshoz kötődő tartalmakat.

${ }^{13}$ A Nemes Nagy Ágnes-féle ,türhetetlen” újra a szétfoszló szövet jelentésmezejébe illeszkedik; a szakasz szóhasználata egyébként feltünően rezonál a Kiss Attila Atilla szerkesztette Helikon-szám korábban idézett abjekció-definíciójára.
} 
vízfelszín szavatolja - egy paradox, kívülről adódó, közvetített azonosságban. A vízfelszín itt olyan tükör, amely a másik által eleve mintázott, kódolt, vagyis a másik szabályai szerint reprezentál, torzít (a hiányt mint többletet, a többletet mint hiányt mutatja). Ha azonban a két szöveghely szemantikai kapcsolódásait tekintjük, a módosító másik rendjébe való beilleszkedésben az azonosulás déja vutapasztalatát érhetjük tetten, amely paradox módon önmaguk felé távolítja a jelentéseket, át- és átjárva az én/másik határvonalán.

A mediált azonosság paradoxonának másik oldala nyilvánul meg a minden bizonnyal irodalmunk egyik ormát jelentő zárósorban is („Az ég s az ég között”). A köztesség feltételez egy másikat, itt tehát egy másik nélküli köztesség paradoxonát kell feloldanunk. Kézenfekvő megoldásként kínálkozik a „kettős világban-létből”, a tükröződésböl eredő hasadtságból kiinduló „az ég és az ég vízfelszíni tükörképe között"-értelmezés, azonban nem tekinthetünk el ilyen könnyen attól, hogy mégiscsak egyetlen kifejezés megismétlése, megkettőzése történik a szövegben, a fenti megkülönböztetés még nem egészen, csak szinte formálódik ki. Ezért sokkal inkább a már említett, a szimbolikus funkció kiindulópontját konstituáló üresség felnyílásának lehetünk itt tanúi, „ami úgy mutatkozik, mint az első elkülönítés aközött, ami még nem Én, és aközött, ami még nem tárgy”. A különbségnek ez az ürje a nyelv feltétele, ugyanakkor a nyelv alapvető játékosságának, instabilitásának, disszeminatív jellegének forrása is - ez vezethet a paradoxon feloldásának következő lépéséhez, miszerint az „ég” jelölő önmagától való elkülönböződése teremti meg a köztességet (ebben az esetben a nyelv eredendő költőisége kapcsán a költői nyelv problematikája is előtérbe kerül).

A Között tava olyan tükör, melyen a jelölök palimpszesztusszerüen gyülnek össze, lokalizálhatatlanná válnak, a mózesi kőtáblák, az erkölcsi világrend jelölői identitásukat vesztik egymásrarétegződésükben, miközben a víz egyértelmüen a megtisztulás helye is, az üresség megtisztításáé, vagyis egyszerre a különbség kríziséé és vágyáé.

Julijana Išpanović Čapo, Kinga Šamu-Končoš, Janoš Šamu

IZMEĐU: KRIZA I ŽELJA. RAZLIKE U POEZIJI AGNEŠ NEMEŠ NAĐ

\section{Rezime}

Agneš Nemeš Nađ je istaknuta mađarska pesnikinja druge polovine dvadesetog veka. Njena poezija je svedočanstvo o istorijskim kataklizmama, o krizi socijalnog/moralnog/jezičkog poretka koji se u psihoanalitičkoj teoriji ličnosti Žak Lakana naziva Simboličkim. Studija detaljno analizira emblematičnu pesmu Nemeš Nađ Između (Között). U njenom pristupu 
figure pesme poetskom destabilizacijom i preusmerivanjem značenja dovode do traumatičnog kolapsa, to jest insceniraju povredu granice između označitelja i označenog, sebe i drugog, tela i jezika. Ovo među-iskustvo opisuje Julija Kristeva sa teoremom abjekta. Abjekt je ne-predmet, ne-objekat, koji povredom granica dovodi integritet subjekta u opasnost jer ga približava zoni u kojoj subjekat još/već ne postoji - jer upravo ova granica/razlika predstavlja osnovu i uslov značenja i(li) identiteta kao takvog. Zrela poezija Agneš Nemeš Nađ nije usmerena prema nekom značenju, nego prema uslovu mogućnosti značenja i identiteta a time istovremeno daje glas i krizi i želji razlike. Studija koristi teorije Julije Kristeve, Žaka Deride, Žorža Didija-Ibermana, Atile Atile Kiš i otvara dijalog sa savremenom recepcijom poezije Agneš Nemeš Nađ.

Ključne reči: Agneš Nemeš Nađ, kriza značenja, svedočanstvo, trauma, istorija recepcije.

\section{IN-BETWEEN: THE CRISIS AND DESIRE OF DIFFERENCE IN THE POETRY OF ÁGNES NEMES NAGY}

\section{Summary}

Ágnes Nemes Nagy is an outstanding Hungarian poet of the second half of the 20th century. Her poetry testifies to the historical cataclysms of the century, a crisis of the social / moral / linguistic order that Jacques Lacan's psychoanalytic subject theory calls Symbolic. The study analyzes the emblematic piece of the Nemes Nagy lyric, the In-Between. In its approach, the poem's rhetorical figures lead to the traumatic collapse of meaning through the poetic betrayal and evasion of meaning, that is to say, the injuries to the boundary between the signifier and the signified, the self and the other, body and language. Julia Kristeva introduces the term abject to capture this in-between experience. The abject is the offending non-object that jeopardizes the integrity of the subject, because it refers to a threatened breakdown in meaning caused by the loss of the distinction between subject and object or between self and other. It leads the subject to a field where the subject is not / is no longer present - the boundary / difference mentioned is the basis and the potential condition of any identity or meaning. For this reason, Ágnes Nemes Nagy's mature poetry is not aimed at any meaning, but rather at the condition of meaning (or identification), expressing at the same time the crisis and the desire for difference. The theoretical basis of the paper is inspired by the works of Julia Kristeva, Jacques Derrida, Georges DidiHuberman and Attila Kiss Attila, from which the analysis is linked to the current discourse of Nemes Nagy Ágnes's reception.

Keywords: Ágnes Nemes Nagy, crisis of meaning, testimony, trauma, history of reception.

$$
\text { KIADÁS }
$$

Nemes Nagy Ágnes, (2003). Összegyüjtött versei. Budapest: Osiris Kiadó 


\section{IRODALOM}

Derrida, J. (2006). Hit és tudás. A „, vallás” a puszta ész határain. Ford. Boros János és Orbán Jolán. Pécs: Brambauer Kiadó

Didi-Huberman, G. (2013). Csillagrepedés. Beszélgetés Hantaival. Ford. Seregi Tamás. Budapest: Mücsarnok Nonprofit Kft.

Gyimesi, T. (1995). Az abjekt Julia Kristeva szubjektumfelfogásában. Helikon, 41, (1-2): 140-142.

Hernádi, M. (2012). A névre szóló és a megnevezhetetlen. Kortárs, http://www.kortarsonline.hu/archivum/2012/07/a-nevre-szolo-es-amegnevezhetetlen.html (2018. 06. 23.)

Kiss, A. A. (1999). Betürés (Posztszemiotikai írások). Szeged: Ictus.

Kiss, A. A. (1995). A szubjektumelméletek néhány kulcsfogalma. Helikon, 41, (12): $155-158$.

Kristeva, J. (2007). A szerelem abjektje. Ford. Gyimesi Júlia. Thalassa, 18, (2-3): 3-27.

Kristeva, J. (1982). Powers of Horror: An Essay on Abjection. New York: Columbia University Press.

Samu-Koncsos, K. (2017). Az elhallgatás poétikája. A tárgyiasság öndekonstrukciója Nemes Nagy Ágnes költészetében. In: (szerk.) [Kiss Ferenc]. Tudomány és erő: Vajdasági Magyar Tudóstalálkozó 2016. Újvidék: VMAT. 25-30. http://vmat.rs/wordpress/wpcontent/uploads/2017/02/VMT_2016-Tudomany_es_ero-Kotet-Teljesdolgozatok.pdf (2018. 07. 22.)

Urbán, P., Z. (2015). Az önreflexió mintázatai Nemes Nagy Ágnes költészetében. Budapest: Ráció Kiadó. 